\title{
Microbial quality of poultry meat in an ISO 22000:2005 certified poultry processing plant of Kathmandu valley
}

\author{
Samita Maharjan ${ }^{*}$, Binod Rayamajhee ${ }^{2}$, Vijay Singh Chhetri ${ }^{3}$, Samendra P. Sherchan ${ }^{4}$, Om Prakash Panta ${ }^{5}$ and \\ Tika Bahadur Karki ${ }^{6}$
}

\begin{abstract}
Poultry meat can be contaminated by different types of microorganisms during processing in processing plant. The microbiological quality of chicken carcasses and along with processing steps and environmental condition was analyzed in this study in an ISO 22000:2005 certified poultry processing plant of Kathmandu. Standard plate count method was applied for the enumeration and detection of total mesophilic bacteria, total coliform, total faecal coliform, Staphylococcus load along with selected pathogens like Salmonella spp., S. aureus, Escherichia coli, Clostridium perfringens, and Listeria spp. in chicken meat at four processing step (evisceration, final washing, frozen and market). It was observed that the level of microbial load decreased with subsequent processing phases in poultry processing plant where high level of bacteria were reduced during final washing and frozen phase. After processing poultry meat in an ISO 22000:2005 certified meat processing plant, total aerobic mesophilic count, total coliform count, total faecal coliform count, total Staphylococcus count were decreased from 6.92 to $4.45 \mathrm{log}$ CFU/g, 3.49 to $2.19 \log$ CFU/g, 2.41 to nil $\log$ CFU/g, and 3.43 to $1.99 \mathrm{log}$ CFU/g respectively. Pathogenic bacteria like Salmonella spp., C. perfringens, and Listeria spp. were absent in chicken meat at the fourth processing step. Prevalence of $E$. coli was reduced from $37.4 \%$ to $10.2 \%$, whereas S. aureus was decreased from $18.57 \%$ to $17.1 \%$. It was concluded that the final washing and freezing steps were the Critical Control Point (CCP) to control microbial hazards in poultry processing phase.
\end{abstract}

Keywords: Poultry processing plant, ISO 22000:2005, HACCP, CCP, Pathogen

\section{Introduction}

Chickens are domestic fowl having red fleshy wattles and combs on their heads raised for meat which are low acid food, rich in nutrients, phosphorous, other minerals, and B-complex vitamins (Gamble, 2015). The consumption of highly nutritious and safe poultry meat has increased worldwide. Globally, in 2013 the average consumption of chicken meat was $15 \mathrm{~kg}$ per person annually (GonzalezOrtiz et al., 2013). According to the Central Bureau of Statistics (CBS) and 'Nepal Commercial Poultry Survey 201415', per capita chicken consumption for Nepali stands about $4.1 \mathrm{~kg}$. According to the statistical information on Nepalese agriculture issued by Ministry of Agriculture

\footnotetext{
* Correspondence: samita.maharjan2015@gmail.com

${ }^{1}$ Department of Quality Control, Valley Cold Store Pvt. Ltd., Balaju,

Kathmandu, Nepal

Full list of author information is available at the end of the article
}

Development (MoAD), Nepal, the total poultry meat production of the country was 55,041 metric ton (MT) in the fiscal year 2015/2016. Government of Nepal had formulated and endorsed the Animal Slaughterhouse and Meat Inspection Act 1999 and regulation 2001 to ensure the quality of meat products. However, there is no meat and meat products standard, while more than 100 food standards have been issued by the government.

The HACCP concept was pioneered in the 1960s, through a joint collaboration between the US National Aeronautics and Space Administration (NASA), Pillsbury Company, and the US Food and Drug Administration (FDA) (Finucane \& Holup, 2005). In the year 2000 , a number of safety standards had developed by many industries which created problems in the implementation of third party audits and certification of food industries. This led to the development of 
International Organization for Standardization (ISO) standards and ISO 22000 food safety management system for the implementation of a HACCP system (Weinroth et al., 2018).

Hazard Analysis and Critical Control Point (CCP) is worldwide recognized scientific system for the identification and to control of physical, chemical and biological hazards in food processing plant and reduce hazard from farm to consumption for safety assurance of food (Panisello et al., 2000). The microbial quality of poultry meat depends on the time of feed withdrawal before slaughter, transportation, contamination from live birds, efficiency of processing method, temperature, sanitary and hygienic condition in the plant (Mead, 2004). The number of contaminating bacteria on poultry carcass may decrease or increase in different processing steps of the plant (Althaus et al., 2017).

In chicken, presence of total mesophilic count is an indicator of hygienic level, total coliform count and total faecal coliform count are indicator of faecal and environment contamination whereas total Staphylococci count and S. aureus count are indicator of poor hygienic, handling and temperature control condition (GonzálezFandos \& Dominguez, 2006; Rindhe et al., 2008) . Presence of food poisoning bacteria in meat is an important public health issue (Mbata, 2005).

HACCP concept was forthput for food processing industry to produce safe food. In Nepal small- and medium-sized food processing industries play an important role in industrial development and food supply. However, they have been suffering from a raw materials of low grades, lack of proper skilled manpower and the problems associated with these things can be reduced by the HACCP concept. HACCP enhanced food safety, cosumer confidence, market access, product consistency while it reduced risk of food borne illenes, production cost, trade risk, public health cost and timely response to the problems (Code, 2012; Satin, 2005). This study was designed with an aim to study the microbial quality of poultry meat at different points of an ISO certified processing plant of Kathmandu valley.

\section{Materials and methods}

Live birds are transported in the poultry processing plant and upon verification by Veterinarians are then processed in the processing phase at 1200 birds/ hours. After humane slaughtering and bleeding for 5 mins transferred in scalding tank for $1.5 \mathrm{~min}$ at $62^{\circ} \mathrm{C}$ which is followed by defeathering, head removal, vent cutting, evisceration, removal of internal organs, lung vacuuming, in-out washing, hock cutting, water chilling (35 mins at $\left.0-5{ }^{\circ} \mathrm{C}\right)$, final washing, vacuum packaging, blast freezing $\left(-30^{\circ} \mathrm{C}\right.$ for $\left.24 \mathrm{~h}\right)$, cold storage $\left(-18^{\circ} \mathrm{C}\right.$ for storage) and market supply as frozen meat as shown in flow chart (Additional file 1).

The study was conducted in an ISO 22000:2005 certified poultry processing plant of Kathmandu valley from July 2016 to December 2016. In July, field observation, case study and preparation were done. Specifically, three times whole chicken samples were aseptically collected from each processing phase (evisceration, final washing, frozen and market) in each month of the study period (August, September, October, November, December). Similarly, altogether 10 water samples (Tank water and Pipeline water), 30 air samples (lairage, bleeding, evisceration, spin chilling, grading, packaging) and 25 equipment samples (packaging material, table, floor, machine, and bucket) were collected and processed in same 5 months. The samples were immediately transferred to microbiology laboratory in sterile plastic bags placed in an insulated ice container and processed on the same day according to the standard laboratory procedure (Food \& D. Administration, 2012).

From whole chicken, 25 gram (gm) of chicken meat samples were cut with its skin by sterilized scissor, and placed in $225 \mathrm{ml}$ of $0.1 \%$ sterilized buffer peptone water (Food \& D. Administration, 2012). The homogenate sample was serially diluted in $9 \mathrm{ml}$ of $0.1 \%$ sterilized buffer peptone water to achieve a 10 -fold dilution. The required dilutions were pour plated on plate count agar, violet red bile agar, M-Endo agar, while spread plated on sterilized Mannitol salt agar. (Maturin \& Peeler, 2001; Bennett et al., 2001; Feng et al., 2002). All inoculated plates were then incubated at $37^{\circ} \mathrm{C}$ for $24-48 \mathrm{~h}$ while M-endo was incubated at $44.5^{\circ} \mathrm{C}$ for $24-48 \mathrm{~h}$. Culture suspected $S$. aureus strain was confirmed by result of Gram staining along with biochemical tests; Catalase, Oxidase, and Coagulase while E. coli was confirmed based on the result of series of biochemical tests; Methyl Red (MR), Voges Proskauer (VP), Oxidase, Catalase, Urea Hydrolysis, Triple Sugar Iron agar (TSI), Citrate utilization, Indole and Sulfide Motility test as recommend by Bailey and Scott's Diagnostic Microbiology (2007).

For the detection of Salmonella spp., $25 \mathrm{~g}$ of chicken meat was enriched in $225 \mathrm{ml}$ of sterile buffered peptone water and incubated at $37^{\circ} \mathrm{C}$ for $24 \mathrm{~h}$. Five $\mathrm{ml}$ preenriched sample was inoculated to $45 \mathrm{ml}$ Selenite-F broth and incubated at $37^{\circ} \mathrm{C}$ for $24 \mathrm{~h}$. A loopful of enriched sample was streaked on Salmonella-Shigella (SS) agar and incubated at $37^{\circ} \mathrm{C}$ for $24 \mathrm{~h}$ (Feng et al., 2002). After culture, isolated colonies were subcultured on MacConkey agar and Nutrient agar for isolation of pure colonies at $37^{\circ} \mathrm{C}$ for $24 \mathrm{~h}$. For the confirmation of isolated pure colonies, different biochemical tests like Methyl Red (MR), Voges Proskauer (VP), Oxidase, Catalase, Urea Hydrolysis, Triple Sugar Iron agar (TSI), 
Citrate utilization, Indole and Sulfide Motility test were performed.

For the isolation and identification of Clostridium perfringens, $25 \mathrm{~g}$ of chicken sample was transferred in 225 $\mathrm{ml}$ of sterile buffered peptone water and an aliquot of 1 $\mathrm{ml}$ from food homogenate was transferred into $9 \mathrm{ml}$ of $0.1 \%$ peptone water then heated at $75^{\circ} \mathrm{C}$ for $20 \mathrm{~min}$. Further dilution was made up to $10^{-6}$ by transferring the 1 $\mathrm{ml}$ aliquot into a tube containing $9 \mathrm{ml}$ sterile buffered peptone water (Solomon \& Lilly Jr, 2001). About 6-7 ml of Tryptose Sulfite Cycloserine Agar (TSC) without egg yolk was poured into petri plates and spread evenly on bottom. After solidification of agar, $1 \mathrm{ml}$ of each dilution sample was transferred into the center of duplicate agar plates. Then, additional $15 \mathrm{ml}$ of TSC agar without egg yolk was poured into plates and mixed well. After solidification, 5-6 $\mathrm{ml}$ of TSC agar was poured to make overlapping (dual layer pour plating). The plates were placed in upright position in anaerobic jar and incubated at $37^{\circ} \mathrm{C}$ for $48 \mathrm{~h}$ (Velugoti et al., 2007).

Twenty five gram of the chicken sample was enriched in $225 \mathrm{ml}$ of Listeria Enrichment broth at $25^{\circ} \mathrm{C}$ for 6 days (Food \& D. Administration, 2012). After incubation, on 3rd and 6th day $1 \mathrm{ml}$ of aliquot was pour plated on Listeria identification agar base (PALCAM) and incubated at $25^{\circ} \mathrm{C}$ for $48 \mathrm{~h}$ (Food \& D. Administration, 2012). After incubation period, grey-green with black center and black halo colonies were subcultured on nutrient agar for isolation of pure culture at $37^{\circ} \mathrm{C}$ for $24 \mathrm{~h}$. Identification of Listeria spp. was done by microscopy, catalase test, oxidase test, biochemical tests, hanging drop motility test, and sugar fermentation test with inverted Durham's tube (Food \& D. Administration, 2012).

Water samples from main tank and pipeline water were collected and microbiologically analyzed for total mesophilic count, total coliform count and total faecal coliform count (Cunniff, 1996). Diluted samples were poured on plate count agar, violet red bile agar and incubated at $37^{\circ} \mathrm{C}$ for $24 \mathrm{~h}$ where M-Endo agar was incubated at $44.5^{\circ} \mathrm{C}$ for $24 \mathrm{~h}$. After incubation, from the countable plates number of colonies between 25 and 250 colonies were counted and expressed in CFU/ml (Cunniff, 1996).

Samples from equipments (packaging material, table, floor, machine, and bucket) used in abattoir were collected by swabbing method. Sterilized swabbing bud was dipped in normal saline $(0.85 \%)$ and drained excess by pressing in side of test tube. With swabbing bud, marked swabbing area $\left(10 \mathrm{~cm}^{2}\right)$ was swabbed in vertical and horizontal position then transferred in test-tube containing $10 \mathrm{ml}$ sterile buffered peptone water (Jørgensen et al., 2002). Then serial dilution was performed as required. Pour plating was done in Plate Count Agar (PCA) then incubated at $37^{\circ} \mathrm{C}$ for
$24 \mathrm{~h}$ and observed for the significant growth of colonies and enumerated accordingly.

Sterilized and air dried solidified Plate Count Agar (PCA) and Potato Dextsrose Agar (PDA) of about 90 $\mathrm{mm}$ diameter (approximate internal area $64 \mathrm{~cm}^{2}$ ) plates were taken and exposed for $15 \mathrm{~min}$ in lairage, bleeding, evisceration, spin chilling, grading, and packaging section of poultry processing plant. Then PCA was incubated at $37{ }^{\circ} \mathrm{C}$ for $24 \mathrm{~h}$ and PDA plates was incubated at $30{ }^{\circ} \mathrm{C}$ for 3-5 days then observed for the significant growth of colonies and enumerated accordingly (Prathab \& Lalitha, 2012).

\section{Data anlysis}

All data were analyzed using SPSS version 21.0. Oneway anova was calculated where $p$ value of $<0.05$ was considered statistically significant at $95 \%$ of confidence level and tukey pairwise comparison was done between processing phase at $95 \%$ confidence. Graphs were plotted using Minitab 18 software.

\section{Results}

Table 1 represents the mean log count of total mesophilic bacterial count, total coliform count, total faecal coliform count and total Staphylococci count enumerated from 60 chicken samples at four different phases of processing line. The results show that higher bacterial load were found in evisceration followed by final washing and frozen and least in market meat. Graph 1 represents interval plot of mean log count vs processing phase (95\% CI for the mean). Bacterial mean log count in evisceration, final washing, frozen and market lies between 3.4-4.8, 2.8-4.2, 1.8-3.2 and 1.6-3.0 respectively. Table 2 shows pairwise comparisons between processing phase using the Tukey Method and 95\% Confidence tukey. This result shows that there is significant difference in bacterial load in first, second and third phases. However, there is no significant difference in the load between last two phases. Table 3 shows one way Anova which represents $p$-value $(0.001)<0.05$, so there is a significant difference in mean bacterial in different phases of processing plant.

Graph 2 shows mean of mean log count of bacterial load in four different phases which illustrates that all bacterial load decreases with processing phases. After washing process, high load of bacteria was found to be decreased in total Staphylococcus count (0.91 log CFU/ g). Total mesophilic count, total coliform count and total faecal coliform count were found to be highly decreased after freezing process by $1.27 \mathrm{log} \mathrm{CFU} / \mathrm{g}, 0.82$ $\log$ CFU/g and 1.84 log CFU/g respectively. However, on moving from frozen to market bacterial load remain constant. Graph 3 represents mean of mean log count of bacterial count with processing phase and month. Bacterial load significantly decreases with processing phase 
Table 1 Mean log count of bacterial load of chicken meat in poultry chain

\begin{tabular}{|c|c|c|c|c|c|}
\hline \multirow{2}{*}{$\begin{array}{l}\text { Sampling } \\
\text { time }\end{array}$} & \multirow{2}{*}{$\begin{array}{l}\text { Biological } \\
\text { hazards }\end{array}$} & \multicolumn{4}{|c|}{ Mean $\log _{10} \mathrm{cfu} / \mathrm{gm}$ at different phases in poultry chain } \\
\hline & & Evisceration & Final washing & Frozen & Market \\
\hline \multirow[t]{4}{*}{ August } & TMC & 7.84 & 5.96 & 4.84 & 4.66 \\
\hline & TCC & 3.4 & 3.3 & 2.2 & 2 \\
\hline & TFCC & 2.24 & 2.2 & 1 & 0 \\
\hline & TSC & 3.25 & 2.4 & 2.2 & 1.9 \\
\hline \multirow[t]{4}{*}{ September } & TMC & 7.65 & 6.04 & 4.64 & 4.60 \\
\hline & TCC & 3.29 & 3.28 & 2.5 & 2.3 \\
\hline & TFCC & 2.25 & 2.2 & 0 & 0 \\
\hline & TSC & 3.04 & 2.38 & 2.1 & 2.08 \\
\hline \multirow[t]{4}{*}{ October } & TMC & 6.29 & 5.6 & 4.04 & 4.0 \\
\hline & TCC & 3.74 & 3 & 2 & 2 \\
\hline & TFCC & 2.69 & 2.3 & 0 & 0 \\
\hline & TSC & 3.47 & 2.25 & 2.04 & 2 \\
\hline \multirow[t]{4}{*}{ November } & TMC & 6.43 & 5.89 & 4.79 & 4.49 \\
\hline & TCC & 3.14 & 2.4 & 2.35 & 2.2 \\
\hline & TFCC & 2.2 & 2 & 1 & 0 \\
\hline & TSC & 3.81 & 3.3 & 2.52 & 1.95 \\
\hline \multirow[t]{4}{*}{ December } & TMC & 6.41 & 5.87 & 4.69 & 4.51 \\
\hline & TCC & 3.86 & 3.73 & 2.53 & 2.43 \\
\hline & TFCC & 2.69 & 2.5 & 0 & 0 \\
\hline & TSC & 3.56 & 2.29 & 2.2 & 2.04 \\
\hline
\end{tabular}

Note

TMC Total Mesophilic Bacterial Count, TCC Total Coliform Count

TFCC Total Faecal Coliform Count, TSC Total Staphylococi Count

whereas environment temperature donot have much effect over it.

The result from Table 4 showed that pathogenic microorganism were analyzed at four different phases of processing plant. During the study the result did not show the presence of Salmonella spp., Clostridium perfringens and Listeria spp. According to this study, prevalence of $E$. coli and $S$. aureus in evisceration stage was found to be $37.4 \%$ and $18.57 \%$ which was eventually decreased to $10.2 \%$ and $17.1 \%$ in market stage respectively.

The Table 5 result showed that 10 water samples of tank water (untreated water) and pipeline water (treated

Table 2 Tukey pairwise comparisons: processing phase grouping information using the Tukey method and 95\% confidence

\begin{tabular}{llllll}
\hline Processing Phase & N & Mean & & \multicolumn{2}{l}{ Grouping } \\
\cline { 5 - 6 } Evisceration & 20 & 4.0625 & A & \\
\hline Final Washing & 20 & 3.4445 & & B & \\
Frozen & 20 & 2.3820 & & & C \\
Market & 20 & 2.1580 & & C \\
\hline
\end{tabular}

Means that do not share a letter are significantly different water- treated by abbaitor water treatment plant and chlorine dosing) were analyzed for total mesophilic bacterial count, total coliform count and total faecal coliform count which were then compared with drinking water standard. Tank water was found out of the standard value however, treated water was within the standard value in terms of total mesophilic count (2.69 log CFU/ $\mathrm{ml}$ ) and absence of total coliform count and total faecal coliform count.

Altogether 30 air samples from processing area of poultry chain was assessed by exposing the plates in different area as shown in Table 6. The total bacterial count were more than total yeast and mold count from all sampling sites. The microbial load was found to be high in lairage section followed by bleeding, evisceration, spin chilling, grading, and least in packaging section. Table 7 represents the microbial load of different sites where 25 swab samples were taken from different equipments used in poultry processing plant (packaging material, table, floor, machine and bucket). Total mesophilic bacterial count was found high in floor and bucket with least contamination in packaging materials. 
Table 3 One-way Anova table

\begin{tabular}{|c|c|c|c|c|c|}
\hline Null hypothesis & All means are equal & & & & \\
\hline $\begin{array}{l}\text { Alternative } \\
\text { hypothesis }\end{array}$ & $\begin{array}{l}\text { Not all means are } \\
\text { equal }\end{array}$ & & & & \\
\hline \multicolumn{6}{|l|}{$\begin{array}{l}\text { Analysis of } \\
\text { Variance }\end{array}$} \\
\hline Source & DF & Adj SS & $\begin{array}{l}\text { Adj } \\
\text { MS }\end{array}$ & $\begin{array}{l}\text { F- } \\
\text { Value }\end{array}$ & $\begin{array}{l}P- \\
\text { Value }\end{array}$ \\
\hline $\begin{array}{l}\text { Processing } \\
\text { Phase }\end{array}$ & 3 & 48.34 & 16.112 & 6.08 & 0.001 \\
\hline Error & 76 & 201.37 & 2.650 & & \\
\hline Total & 79 & 249.71 & & & \\
\hline
\end{tabular}

Conclusion: Since $p$-value $(0.001)<0.05$, we reject our null hypothesis

\section{Discussion}

As the result of the highest count was observed in evisceration and final washing stage,which was decreased during in final washing after evisceration, the number of total mesophilic bacterial count by more than 1 log cycle which is compatible with a report reported by Goksoy et al. (2004) (James et al., 2000). Nevertheless, the rate of decrease in total coliform count, total faecal coliform count and total Staphylococci count were less compatible which may be due to the strong attachment of these microorganism in chicken and less effective of washing process applied in the plant (Althaus et al., 2017).

A significant changes in bacterial count occurred at freezing steps which reduced the number of total bacterial count by 1 log cycle. Cooling and freezing of poultry meat has great influence on poultry meat microflora as cold condition has reduced microorganisms (James et al., 2006). During freezing of poultry the destruction of microorganisms occurs but this destruction is never absolute and is only interested in a limited number of microorganisms, which may be higher or lower depending on type of microorganisms (Mbata, 2005).

The total aerobic plate count $4.45 \mathrm{log}$ CFU/g in market meat of this study is consistent with previous studies conducted by Chaudhey et al. (2011) (5.07 log CFU/g) (Chaudhrya et al., 2011). Sengupta et al. (2012), Omorodion and Odu (2014), and Bhandari et al. (2013) have reported higher counts of total aerobic bacteria $6.39 \mathrm{log}$ $\mathrm{CFU} / \mathrm{g}, 5.96 \log \mathrm{CFU} / \mathrm{g}$ and $7.24 \mathrm{log} \mathrm{CFU} / \mathrm{g}$ respectively in market chicken meat (Ibrahim et al., 2015; Omorodion \& Odu, 2014; Bhandari et al., 2013). On the other hand, lower counts were reported by Rindhe et al.
(2008) (3.67 log CFU/g) (Rindhe et al., 2008), and Aljasser et al. (2012) (4.03 log CFU/g) (Al-Jasser, 2012). Total viable count in raw poultry indicates hygienic conditions of processing plants under which the food are processed and high load increases the risk of microbial spoilage (Cohen et al., 2007; Javadi \& Safarmashaei, 2011). Studies have shown the correlation of food spoilage with the total bacterial count on the surface part of carcass: off-odor and sour are the noticeable evident when the bacterial count on carcass reached about $10^{7}$ $\mathrm{CFU} / \mathrm{g}$ and visible slime formation can be observed when the count reached approximately $10^{8} \mathrm{CFU} / \mathrm{g}$ threshold (Wabeck, 2002).

In this study, total coliform count $2.19 \mathrm{log}$ CFU/g of market meat was similar with results reported by Capita et al. (2002) (2.7 log CFU/g) and Northcutt et al. (2003) (2.6 log CFU/g) (Capita et al., 2002; Northcutt et al., 2003). In contrast, less coliform counts were reported by Joshi et al. (1.03 $\log$ CFU/g) and Selvan et al. (2007) (1.13 log CFU/g) (Joshi \& Joshi, 2010; Selvan et al., 2007) while higher coliform counts were found in studies conducted by Kumar et al. (2012) (4.97 log CFU/g), Sengupta et al. (2012) (32.2 log $\mathrm{CFU} / \mathrm{g}$ ), and Bhandari et al. (2013) (6.5 log CFU/g) (Ibrahim et al., 2015; Bhandari et al., 2013; Selvan et al., 2007). In this study, total faecal coliform count was absent in market meat. E. coli was used as an indicator organism of sanitary quality and potential faecal contamination of meat which can originate even from workers or environment of the processing plant (Wabeck, 2002). E. coli count in poultry products can be minimized by controlling cross contamination, maintaining sanitary practices, and temperature of carcass. It is necessary to ensure hygienic food production for the safeguard of public health (Althaus et al., 2017).

The count of total Staphylococci $1.99 \log \mathrm{CFU} / \mathrm{g}$ in market meat was lower than the studies carried by Sengupta et al. (2012) (3.7 log CFU/g), Joshi et al. (2010) (4.07 log CFU/g) (Joshi \& Joshi, 2010; Sengupta et al., 2012). Presence of Staphylococci in meat reflects insanitary condition, cross contamination between processing phase, and surrounding environment, processing temperature and personal contact. Staphylococcus aureus is a commensal organism of human skin and also a common pathogen, which causes minor to severe infections including food poisoning (Carroll et al., 2015). In a study conducted by

Table 4 Occurrence of pathogenic microorganism at 4 processing phases of the processing phase

\begin{tabular}{llllll}
\hline Processing stage & E. coli & S. aureus & Salmonella spp. & Clostridium perfringens & Listeria spp. \\
\hline Evisceration & $37.4 \%$ & $18.57 \%$ & - & - & - \\
Final washing & $22.8 \%$ & $19.4 \%$ & - & - & - \\
Frozen & $11.4 \%$ & $17.1 \%$ & - & - & - \\
Market & $10.2 \%$ & $17.1 \%$ & - & - \\
\hline
\end{tabular}


Table 5 Parameters of water samples from the poultry processing plant

\begin{tabular}{llll}
\hline Water sources & \multicolumn{3}{l}{ Mean bacterial count (log CFU/ml water) } \\
\cline { 2 - 4 } & $\begin{array}{l}\text { Total mesophilic } \\
\text { bacterial count }\end{array}$ & $\begin{array}{l}\text { Total } \\
\text { coliform } \\
\text { count }\end{array}$ & $\begin{array}{l}\text { Total faecal } \\
\text { coliform count }\end{array}$ \\
\hline $\begin{array}{l}\text { Tank water } \\
\text { (untreated water) }\end{array}$ & 3.2 & 1.2 & - \\
$\begin{array}{l}\text { Pipeline water } \\
\text { (treated water) }\end{array}$ & 2.5 & - & - \\
$\begin{array}{l}\text { Drinking water } \\
\text { standard }\end{array}$ & 2.69 & - & - \\
\hline
\end{tabular}

Hotee et al. (2011) at the Central Health Laboratory in Mauritius have isolated $S$. aureus as the second common pathogen from analyzed food samples (Heetun et al., 2015). The presence of $17.1 \%$ S. aureus in market meat of this study is in agreement with the study conducted Kozacins et al. (2012) where prevalence was 17.9\% (Kozačinski et al., 2012). In contrast, Joshi and Joshi (2010) had reported higher prevalence of S. aureus (100\%) in meat (Joshi \& Joshi, 2010). Generally chicken meat becomes contaminated with $S$. aureus when an infected person does coughing, sneezing, talking or breathing inside the plant (Wabeck, 2002). The microbial load were found in initial processing step, comprising the receiving-killing and defeathering areas, whereas count towards the evisceration, air chilling, packaging and dispatch area decreased (James et al., 2000; Hinton Jr et al., 2004).

Another important pathogen of meat contamination is Salmonella which habitats in the intestinal tract of animals and shed along with feces of the animals that makes its presence in surrounding environment (Wabeck, 2002). In this study, Salmonella spp. was not detected in market chicken meat. As we applied plating culture technique for the isolation of Salmonella spp. so we can't claim that Salmonella spp. were completely absent. There could be viable but non-culturable cells of the strain. Similar findings have been reported by Vaidya et al. (2005), and Lindblad et al. (2006) (Vaidya et al., 2005; Lindblad et al., 2006). In contrast, in another study carried by Joshi and Joshi (2010) had reported Salmonella spp. in all the examined chicken carcasses (100\%) (Joshi \& Joshi, 2010). On the other hand, lower percentage of Salmonella spp. was reported by Cohen et al. (2007) (1.6\%); Abdellah et al. (2008) (2.08\%); Colmegna et al. (2009) (1.1\%) (Cohen et al., 2007; Abdellah et al., 2008; Colmegna et al., 2009). Presence of Salmonella spp. in market meat of chicken suggests poor hygienic status of meat processing plant during slaughtering, cross contamination between machines, scalding tanks, defeathering machines, and workers. During the slaughtering and manual evisceration process of intestinal contents may spill and contaminate the muscle and organs of the chicken which is an important source of Salmonella spp. contamination in meat and water chilling tanks (Colmegna et al., 2009).

Clostridium perfringens is an obligate anaerobe which is found in the alimentary tract of poultry. C. perfringens was not isolated in chicken meat samples of this study which complies with the study carried by Shaltout et al. (2009) in Egypt (Shaltout, 2009). On the other hand, C. perfringens were isolated by Chhetri and Karki (2014) $(80.8 \%)$ in raw poultry meat of Kathmandu; Nowell et al. (2010) (66\%) in Canada; Cohel et al. (2007) (7.2\%) in Casablanca (Morocco) and Thangamani and Subramanin (2012) (3.81\%) in Tamilnadu, India (Cohen et al, 2007; Nowell et al., 2010; Thangamani \& Subramanian, 2012; Chhetri \& Karki, 2014). If the raw meat originally contains $C$. perfringens, it is almost impossible to make final product free from this contamination since heat treatment only destroys vegetative cells of this bacterium activating spores for further germination (Van Immerseel et al., 2004).

Listeria spp. do spread either by inhalation or direct contact. Listeriosis typically occur after consumption of contaminated foods. For humans contaminated sources include raw meat (Reiter et al., 2005). In this study, Listeria spp. was not isolated from the chicken meat

Table 6 Mean log count of microorganism isolated from surrounding air of different section of processing plant

\begin{tabular}{lll}
\hline Sampling site & Mean count (CFU/15 min) & \\
\cline { 2 - 3 } & Total mesophilic bacterial count & Total yeast and mold count \\
\hline Lairage section & $*$ & 1.2 \\
Bleeding section & 1.65 & 1.14 \\
Evisceration section & 1.55 & 0.95 \\
Spin chilling section & 1.53 & 1.08 \\
Grading section & 1.45 & 0.93 \\
Packaging section & 1.43 & \\
\hline
\end{tabular}


Table 7 Mean log count of microorganism isolated from different equipment used in processing plant

\begin{tabular}{ll}
\hline Sampling area & $\begin{array}{l}\text { Mean log CFU per } 10 \mathrm{~cm}^{2} \\
\text { Total mesophilic } \\
\text { bacterial count }\end{array}$ \\
\hline Packaging material & 2.18 \\
Table & 4.07 \\
Floor & 5.43 \\
Machine & 4.36 \\
Bucket & 5.37 \\
\hline
\end{tabular}

samples during the slaughter process which was similar with another study reported by Svobodova et al. (2012) (Svobodová et al., 2012). Prevalence of L. monocytogenes was reported by Colmegna et al. (2009) (3\%) in Milano, Italy; Kozacins et al. (2012) (4.5\%) in Croatia; Molla et al. (2004) (1.9\%) in Addis Ababa, Ethiopia and Cohen et al. (2007) (0.5\%) in Casablanca (Morocco) (Cohen et al., 2007; Kozačinski et al., 2012; Colmegna et al., 2009; Molla et al., 2004). Loura et al. (2004) have reported frequent findings of $L$. monocytogenes on poultry cuts and especially, on the hands of poultry processing plant staffs, poultry processing plant desks and equipment (Gottlieb et al., 2006). L. monocytogenes is well documented as a major foodborne pathogen in the different parts of the world which is habitat event in natural environments like mud, soil, water, sewage, gut of poultry and feces (Yeh, 2004).

The tank water is present with high load of total viable count $3.2 \log \mathrm{CFU} / \mathrm{ml}$ and coliform $1.2 \log \mathrm{CFU} / \mathrm{ml}$. After water treatment in water treatment plant and chlorine dosing, processing water (Pipeline water) is nearly free of contamination showing acceptable microbiological water quality with total viable count of $2.5 \mathrm{log}$ $\mathrm{CFU} / \mathrm{ml}$, nil coliform and faecal coliform. The total plate count is an indirect indicator or index for pathogens of concern in water, which helps in assessing the efficacy and proper functioning of water treatment and supply process and is related to the acceptability of water (Figueras \& Borrego, 2010).

Air microflora in abattoir changes with rate of movement of people from one place to another, hygienic condition, humidity and room temperature (Haagsma et al., 2012). So, in order to monitor air quality, the plate exposure method was applied in this study for total mesophilic bacterial count and total yeast and mold count which showed that lairage was most contaminated whereas packaging, grading, and spin chilling section showed least contamination.. The presence of fungi in abattoir air may be due to migration from outdoor environment as well as presence in ceilings and walls of production area (Update, E. H. E. D. G, 2006). In poultry processing plants, the reception of birds is the major source of air pollution with pathogenic microorganisms. Along the processing phase of poultry processing plant air microflora tends to decrease reaching the lowest values in the freezing (Whyte et al., 2001). Findings of this stay are in agreement with the data reported by Whyte et al. (2001), they have reported that microbial contamination of the air was widespread and varied considerably between different processing locations of a poultry processing plant (Whyte et al., 2001).

The presence of high load of bacteria on the floor poultry processing plant may be due to cross- contamination of litter as chicken faeces are rich in microorganisms (Svobodová et al., 2012). During this study, the cleanliness of table, equipment, machine, buckets used in the poultry processing were assessed to check the standards of hygiene and efficiency of cleaning procedures. In this study, there was high load of total mesophilic bacterial count indicating lack of good cleaning practices which ultimately played a great role in cross-contamination of poultry meat. Contaminating bacteria on the equipment would soon be found on meat in various parts of the carcasses by increasing their microbial load and reducing their storage quality and safety (Bhaisare et al., 2014). Implementation of HACCP system in the food industry and even in home can maintain food safety by eliminating or reducing food-borne hazards (Wallace, 2014). Many researches have shown that application of HACCP systems in food industry leads to more efficient prevention of food-borne diseases (Scoti \& Stevenson, 2006; Pal et al., 2016).

\section{Conclusion}

This study shows that microbial load was found to be slowly decreased with further processing steps whereas month/weather have no effect in microbial load in an ISO 22000:2005 certified poultry processing plant in Kathmandu valley. The final washing, and freezing phases are determined as Critical Control Point (CCP) to combat microbial hazard because, besides this, on poultry processing phase, there are no additional reducing operations for reducing the contamination at acceptable level. In the poultry processing plant, microbial contamination of poultry meat occur in every phase of processing so it can be reduced by implementation of good manufacturing practice, proper use of sanitation equipment, proper clean in place system, use of contamination free water, good personnel hygiene, and training of plant workers.

\section{Limitations}

Due to short duration of study we couldn't collect and investigate meat samples from other poultry processing plants of the city. So, we can't reveal the exact figure of 
microbial load in chicken meat at different points of other processing plant. Further study in poultry meats of different sites of the country is recommended to generalize the result on implementation of HACCP principles in poultry processing plants.

\section{Supplementary information}

Supplementary information accompanies this paper at https://doi.org/10. 1186/s40550-019-0078-5.

Additional file 1: Flow chart and major sampling points $\left({ }^{*}\right)$

Additional file 2: Graphs

\section{Abbreviations}

CBS: Central bureau of statistics; CCP: Critical control point; CFU: Control forming unit; FDA: Food and drug administration; HACCP: Hazard analysis critical control point; ISO: International organization for standardization; MoAD: Ministry of agriculture development; MR: Methyl Red; MSA: Mannitol salt agar; MT: Metric ton; NASA: National aeronautics and space administration; PALCAM: Listeria identification agar base; PCA: Plate count agar; PDA: Potato dextrose agar; SOP: Standard operating procedures; SS: Salmonella-Shigella agar; TQM: Total quality management; TSC: Tryptose sulfite cycloserine agar; TSI: Triple sugar iron agar; VP: Voges proskauer

\section{Acknowledgements}

We would like to acknowledge Valley Cold Store Pvt. Ltd., Balaju, Kathmandu for providing required laboratory facilities for the completion of this study.

\section{Ethics and consent to participate}

Not applicable

\section{Authors' contributions}

First author: SM is primary author who designed the study methodology, performed laboratory investigations and prepare the manuscript. Second authors: BR and SS edited, proof read, helped in data analysis and revised the complete manuscript for submission. VSC, OPP, and TBK helped in data analysis and proof read of the manuscript. All authors approved the final manuscript before submission to the International Journal of Food Contamination, BMC.

\section{Funding}

Not applicable

\section{Availability of data and materials}

The datasets used and analysed during this study are available in excel sheets which can be obtained from the corresponding author on reasonable request.

\section{Consent for publication}

Not applicable

\section{Competing interests}

The authors declare that they have no competing interests.

\section{Author details}

${ }^{1}$ Department of Quality Control, Valley Cold Store Pvt. Ltd., Balaju, Kathmandu, Nepal. ${ }^{2}$ Department of Infectious Diseases and Immunology, Kathmandu Research Institute for Biological Sciences, Lalitpur, Nepal. ${ }^{3}$ School of Nutrition and Food Sciences, Louisiana State University, Baton Rouge, USA. ${ }^{4}$ Department of Global Environmental Health Sciences, School of Public Health and Tropical Medicine, Tulane University, New Orleans, LA, USA. ${ }^{5}$ Department of Microbiology, National College, Khusibu, Kathmandu, Nepal. ${ }^{6}$ Department of Biotechnology, Kathmandu University, Dhulikhel, Kavre, Nepal.
Received: 19 June 2019 Accepted: 9 October 2019

Published online: 30 November 2019

\section{References}

Abdellah C, Fouzia RF, Abdelkader C, Rachida SB, Mouloud Z. Occurrence of Salmonella in chicken carcasses and giblets in Meknes-Morocco. Pak J Nutr. 2008;7(2):231-3.

Al-Jasser MS. Effect of cooling and freezing temperatures on microbial and chemical properties of chicken meat during storage. J Food Agric Environ. 2012;10:113-6.

Althaus D, Zweifel C, Stephan R. Analysis of a poultry slaughter process: influence of process stages on the microbiological contamination of broiler carcasses. Italian J Food Saf. 2017;6(4).

Bennett, Reginald W., Jennifer M. Hait, and Sandra M. Tallent. "Staphylococcus aureus." Guide to foodborne pathogens (2001): 201-220.

Bhaisare DB, Thyagarajan D, Churchil RR, Punniamurthy N. Bacterial pathogens in chicken meat: review. Int J Life Sci Res. 2014;2(3):1-7.

Bhandari N, Nepali DB, Paudyal S. Assessment of bacterial load in broiler chicken meat from the retail meat shops in Chitwan, Nepal. Int J Infect Microbiol. 2013;2(3):99-104

Capita R, Alonso-Calleja C, García-Arias MT, Moreno B, Del Camino GarcíaFernández M. Methods to detect the occurrence of various indicator bacteria on the surface of retail poultry in Spain. J Food Sci. 2002; 67(2):765-71.

Carroll, Karen C., Janet S. Butel, and Stephen A. Morse. Jawetz Melnick \& Adelbergs Medical Microbiology 27 E. McGraw Hill Professional, 2015.

Chaudhrya M, Rashidb H, Hussainc M, Rashidd HB. Evalution of bacteriological quality of whole chicken carcasses with and without skin by comparing level of indicator bacteria. Sci Int (Lahore). 2011;23(4):307-11.

Chhetri VS, Karki TB. Occurrence of Clostridium perfringens in raw meat, poultry and meat spices and effect of sodium chloride and reduced $\mathrm{pH}$ on the outgrowth of their spores. Asian Jr of Microbiol Biotech Env Sc. 2014;16(4): $885-9$

Code, Food. "Recommendations of the United States Public Health Service Food and Drug Administration."National Technical Information Service Publication PB2009112613. Accessed 10, no. 1 (2009): 2012

Cohen N, Ennaji H, Bouchrif B, Hassar M, Karib H. Comparative study of microbiological quality of raw poultry meat at various seasons and for different slaughtering processes in Casablanca (Morocco). J Appl Poult Res. 2007:16(4):502-8.

Colmegna S, Invernizzi A, Mascher AL, Corsale E, Ferrazzi V, Grilli G. Microbiological characteristics of poultry meats-Results of inspections carried out in the province of Milano, Italy. Ital J Anim Sci. 2009;8(4):765-70.

Cunniff, Patricia. Official methods of analysis of AOAC International. No. Sirsi) i9780935584547. Association of Official Analytical Chemists. 1996.

Feng, P., Weagant, S.D., Grant, M.A., Burkhardt, W., Shellfish, M. and Water, B., 2002. BAM: enumeration of Escherichia coli and the coliform Bacteria. Bacteriological analytical manual, pp13-19.

Figueras MA, Borrego JJ. New perspectives in monitoring drinking water microbial quality. Int J Environ Res Public Health. 2010;7(12):4179-202.

Finucane ML, Holup JL. Psychosocial and cultural factors affecting the perceived risk of genetically modified food: an overview of the literature. Soc Sci Med. 2005;60(7):1603-12.

Food, U. and D. Administration, Bacteriological analytical manual, chapter 1, Food sampling/Preparation of sample homogenate, 2012

Gamble, H. R. "Trends in food production practices relative to foodborne parasites." Foodborne parasites in the food supply web, pp. 11-22. 2015

González-Fandos E, Dominguez JL. Efficacy of lactic acid against Listeria monocytogenes attached to poultry skin during refrigerated storage. J Appl Microbiol. 2006;101(6):1331-9.

Gonzalez-Ortiz G, Sala R, Canovas E, Abed N, Barroeta AC. Consumption of dietary n-3 fatty acids decreases fat deposition and adipocyte size, but increases oxidative susceptibility in broiler chickens. Lipids. 2013;48(7): 705-17.

Gottlieb SL, Newbern EC, Griffin PM, Graves LM, Hoekstra RM, Baker NL, Hunter SB, et al. Multistate outbreak of listeriosis linked to turkey deli meat and subsequent changes in US regulatory policy. Clin Infect Dis. 2006:42(1):29-36

Haagsma JA, Tariq L, Heederik DJ, Havelaar AH. Infectious disease risks associated with occupational exposure: a systematic review of the literature. Occup Environ Med. 2012;69(2):140-6. 
Heetun I, Goburdhun D, Neetoo H. Comparative microbiological evaluation of raw chicken from markets and chilled outlets of Mauritius. J Worlds Poul Res. 2015;5(1):10-8.

Hinton A Jr, Cason JA, Ingram KD. Tracking spoilage bacteria in commercial poultry processing and refrigerated storage of poultry carcasses. Int J Food Microbiol. 2004;91(2):155-65.

Ibrahim HM, Amin RA, El-Shater MA, Hafez SM. Bacteriological evaluation of freshly slaughtered chicken carcasses. Benha Vet Med J. 2015;28:74-82.

James C, Göksoy EO, Corry JEL, James SJ. Surface pasteurization of poultry meat using steam at atmospheric pressure. J Food Eng. 2000;45(2):111-7.

James C, Vincent C, de Andrade Lima TI, James SJ. The primary chilling of poultry carcasses-a review. Int J Refrig. 2006;29(6):847-62.

Javadi A, Safarmashaei S. Microbial profile of marketed broiler meat. Middle-East J Sci Res. 2011

Jørgensen F, Bailey R, Williams S, Henderson P, Wareing DRA, Bolton FJ, Frost JA, Ward L, Humphrey TJ. Prevalence and numbers of Salmonella and Campylobacter spp. on raw, whole chickens in relation to sampling methods. Int J Food Microbiol. 2002;76(1-2):151-64.

Joshi N, Joshi RK. Bacteriological quality of meat sold in retail market in Uttar Pradesh. J Vet Public Health. 2010;8(2):137-9.

Kozačinski L, Fleck ŽC, Kozačinski Z, Filipović I, Mitak M, Bratulić M, Mikuš T. Evaluation of shelf life of pre-packed cut poultry meat. Veterinarski Arhiv. 2012;82(1):47-58

Lindblad M, Lindmark H, Thisted Lambertz S, Lindqvist R. Microbiological baseline study of broiler chickens at Swedish slaughterhouses. J Food Prot. 2006; 69(12):2875-82.

Maturin, L. J., and James T. Peeler. "Aerobic plate count." Bacteriological analytical manual 8 (2001)

Mbata TI. Poultry meat pathogens and its control. Internet J Food Saf. 2005;7:20-8.

Mead GC. Microbiological quality of poultry meat: a review. Revista Brasileira de Ciência Avícola. 2004;6(3):135-42.

Molla B, Yilma R, Alemayehu D. Listeria monocytogenes and other Listeria species in retail meat and milk products in Addis Ababa, Ethiopia. Ethiop J Health Dev. 2004;18(3):208-12

Northcutt JK, Berrang ME, Dickens JA, Fletcher DL, Cox NA. Effect of broiler age, feed withdrawal, and transportation on levels of coliforms, Campylobacter, Escherichia coli and Salmonella on carcasses before and after immersion chilling. Poult Sci. 2003:82(1):169-73.

Nowell VJ, Poppe C, Parreira VR, Jiang Y-F, Reid-Smith R, Prescott JF. Clostridium perfringens in retail chicken. Anaerobe. 2010;16(3):314-5.

Omorodion NJPN, Odu NN. Microbiological quality of meats sold in port Harcaurt Metropolis, Nigeria. Nat Sci. 2014;12(2):58-62.

Pal M, Gebregabiher W, Singh RK. The role of Hazard Analysis Critical Control Point in food safety; 2016.

Panisello PJ, Rooney R, Quantick PC, Stanwell-Smith R. Application of foodborne disease outbreak data in the development and maintenance of HACCP systems. Int J Food Microbiol. 2000;59(3):221-34.

Prathab AG, Lalitha C. Microbiological surveillance of air quality in operation theatres-comparison of the conventional settle plate techniques vs use of an air sampling device. J Evol Med Dent Sci. 2012;1(4):371.

Reiter MGR, Bueno CMM, Lopez C, Jordano R. Occurrence of Campylobacter and Listeria monocytogenes in a poultry processing plant. J Food Prot. 2005;68(9):1903-6.

Rindhe SN, Zanjad PN, Doifode VK, Siddique A, Mendhe MS. Assessment of microbial contamination of chicken products sold in Parbhani city. Veterinary World. 2008;1(7):208.

Satin M. Quality enhancement in food processing through HACCP (Hazard analysis and critical control point); 2005.

Scoti UN, Stevenson KE. HACCP: a systematic approach to Food safety, Food products association; 2006.

Selvan P, Narendra B, Sureshkumar S, Venkatamanujam V. Microbial quality of retail meat products available in Chennai city. Am J Food Technol. 2007;2(1):55-9.

Sengupta R, Das R, Ganguly S, Mukhopadhayay SK. Commonly occurring bacterial pathogens affecting the quality of chicken meat. Int J Chem Biochem Sci. 2012:1:21-3.

Shaltout FA. Microbiological Quality of Chicken Carcasses at Modern Poultry Plant. Third Inter Sci Conf. 2009;29.

Solomon, Haim M., and Timothy Lilly Jr. "BAM: Clostridium botulinum." Bacteriological analytical manual (2001).

Svobodová I, Bořilová G, Hulánková R, Steinhauserová I. Microbiological quality of broiler carcasses during slaughter processing. Acta Vet Brno. 2012;81(1):37-42.
Thangamani A, Subramanian S. Prevalence of Clostridium perfringens in the chicken meat rendered at retail outlets of Namakkal, Tamilnadu. J Adv Vet Res. 2012;2(3):157-9.

Update, E. H. E. D. G. Guidelines on air handling in the food industry. Trends Food Sci Technol. 2006:17:331-6.

Vaidya VM, Paturkar AM, Waskar VS, Zende RJ, Rawool DB. Detection of indicator organisms on poultry carcass sites in an organized slaughterhouse. J Muscle Foods. 2005;16(4):289-97.

Van Immerseel F, De Buck J, Pasmans F, Huyghebaert G, Haesebrouck F, Ducatelle R. Clostridium perfringens in poultry: an emerging threat for animal and public health. Avian Pathol. 2004;33(6):537-49.

Velugoti PR, Rajagopal L, Juneja V, Thippareddi H. Use of calcium, potassium, and sodium lactates to control germination and outgrowth of Clostridium perfringens spores during chilling of injected pork. Food Microbiol. 2007; 24(7-8):687-94.

Wabeck CJ. Quality Assurance and Food Safety-Chicken Meat. In: Commercial Chicken Meat and Egg Production. Boston: Springer; 2002. p. 871-87.

Wallace CA. Food safety assurance systems: Hazard analysis and critical control point system (HACCP): Principles and practice; 2014. p. 226-39.

Weinroth MD, Belk AD, Belk KE. History, development, and current status of food safety systems worldwide. Animal Frontiers. 2018;8(4):9-15.

Whyte PJDC, Collins JD, McGill K, Monahan C, O'mahony H. Distribution and prevalence of airborne microorganisms in three commercial poultry processing plants. J Food Prot. 2001;64(3):388-91.

Yeh, Emily T. "Characterization of Listeria monocytogenes isolated from retail organic chicken." PhD diss., 2004.

\section{Publisher's Note}

Springer Nature remains neutral with regard to jurisdictional claims in published maps and institutional affiliations.
Ready to submit your research? Choose BMC and benefit from:

- fast, convenient online submission

- thorough peer review by experienced researchers in your field

- rapid publication on acceptance

- support for research data, including large and complex data types

- gold Open Access which fosters wider collaboration and increased citations

- maximum visibility for your research: over $100 \mathrm{M}$ website views per year

At BMC, research is always in progress.

Learn more biomedcentral.com/submissions 